\title{
COVID 19: THE IMPACT OF DEMAND, SUPPLY, AND LABOR
}

\author{
Hantono ${ }^{* 1}$ 瓜 \\ ${ }^{* 1}$ Faculty of Economy, Accounting, University of Pelita Harapan, Campus Medan, North Sumatera, \\ Indonesia
}

DOI: https://doi.org/10.29121/IJOEST.v4.i5.2020.105

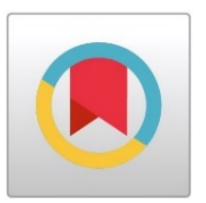

Article Type: Research Article

Article Citation: Hantono. (2020).

COVID 19: THE IMPACT OF

DEMAND, SUPPLY, AND LABOR.

International Journal of Engineering

Science Technologies, 4(5), 60-73.

https://doi.org/10.29121/IJOEST.v

4.i5.2020.105

Received Date: 26 August 2020

Accepted Date: 3 October 2020

Keywords:

Demand

Supply

Labor

COVID 19

\section{ABSTRACT}

This study aims to determine the effect of 1) demand, 2) supply, 3) labor, 4) covid 19. The sampling in this research was conducted by using a incidental sampling method. Methods of data collection through questionnaires that have been distributed to 100 respondents who have met criteria. With multiple linear regression analysis, it shows that the demand, supply, labor both partial and simultaneous have significant effect on covid 19. It can be concluded that mitigation of demand, supply, labor towards covid 19. The results of t test showed that demand is approved and indicates demand has great impact on affecting the covid 19, supply is not approved and indicates supply has less impact on affecting the covid 19, labor is approved and indicates labor has great impact on affecting the covid 19. The results of $f$ test showed that both of the independent variables are simultaneously affecting the covid 19 . The result of $\mathrm{R}$ Square of the regression model is 0.216 which shows that $21,6 \%$ of mitigation of covid 19 can be explained by demand, supply, labor. Whereas, the $78,4 \%$ of covid 19 variable can be explained by other factors or variables which are not examined in this research.

\section{INTRODUCTION}

In accordance with economic law, this phenomenon is a natural thing, where there is an increase in demand, the price of goods will soar. This will have an impact on the increase in prices of goods continuously due to high demand. Just before fasting, rising prices of goods occur due to high demand, but the amount of supply of goods available on the market is fixed or tends to decrease. If we want to control the price one way is to increase the number of offers on the market, which means we increase the stock of goods in the market or by suppressing the demand for the goods. In accordance with the law of demand and supply if the supply of an item increases but the demand for that item decreases, the price of the product will decrease.

In early March 2020, Indonesia began a war against the Corona Virus pandemic (Virus Covid 19) which began to enter Indonesia. Of course, with the first entry of Corona Virus (Covid Virus 19) in Indonesia will have an indirect impact on the Indonesian state which is most felt is the impact of the Indonesian economy. For information, Corona Virus (Covid Virus 19) is an infectious disease caused by the most recently discovered coronavirus. This new virus and disease were not known before the outbreak began in Wuhan, China, in December 2019 and is still ongoing. Even in March the WHO announced that the Corona Virus (Covid Virus 19) was a global pandemic that had to be resolved together because it had spread in every country. A survey conducted by Facebook shows that with the entry of Corona Virus (Covid Virus 19) in Indonesia, almost 80\% of respondents from the country of Indonesia are afraid

(C) 2020 The Author(s). This is an open access article distributed under the terms of the Creative Commons Attribution License, which permits unrestricted use, distribution, and reproduction in any medium, provided the original author and source are credited. 
of contracting Corona Virus (Covid Virus 19), of course this is based on the absence of a vaccine to overcome Corona Virus ( Covid Virus 19) throughout the World (https://idcloudhost.com/Explore how the impact of Corona Virus (Covid-19) on the Indonesian economy n.d.).

\section{LITERATURE REVIEW}

\subsection{DEMAND}

Demand is understood as reflection of needs of people for these or those goods, service, their desire to buy (L.N., Safiullin, OduntsovaJ. L. 2015).

Demand is the want or desire to possess a good or service with the necessary goods, services, or financial instruments necessary to make a legal transaction for those goods or services (Moffatt n.d.)

Economists use the term demand to refer to the amount of some good or service consumers are willing and able to purchase at each price. Demand is fundamentally based on needs and wants, if you have no need or want for something, you won't buy it (Greenlaw, Steven. A., David Shapiro 2018).

Demand in economics is the consumer's desire and ability to purchase a good or service. It's the underlying force that drives economic growth and expansion (Amadeo n.d.)

Demand is a price and quantity relationship. It tells the quantity of a product that will be demanded at various price levels. So, demand is not one quantity demanded but a series of quantities demanded based on alternative prices (Hofstrand 2019).

The demand is usually defined as a schedule of quantities that buyers are willing and able to purchase at a schedule of prices in a given time interval (ut), ceteris paribus (Reynolds 2011).

Demand is a schedule, graph or equation showing the amounts of a good consumers are both willing and able to purchase at a specified set of prices over a specific time period (Debertin 2012)

The most important other factors that can affect demand are:

- The buyers' income.

- Prices and price changes on other goods. We will make a distinction between complementary goods and substitute goods.

- Preferences. What consumers demand is largely a matter of taste. If there is a change in taste, there is usually also a change in demand (Ahlersten n.d.)

The main features of demand for a commodity are:

- Demand depends upon utility of the commodity. A consumer is rational and demands only those commodities which provide utility.

- Demand always means effective demand i.e., demand for a commodity or the desire to own a commodity should always be backed by purchasing power and willingness to spend.

- Demand is a flow concept, i.e., so much per unit of time.

- Demand means demand for final consumer goods.

- Demand is a desired quantity. It shows consumer's wish or need to buy the commodity (Deepashree 2018)

\subsection{SUPPLY}

Supply is a schedule, graph or equation showing the amounts of a good that producers are both willing and able to produce at a specified set of prices over a specific period of time (Debertin 2012).

When economists talk about supply, they mean the amount of some good or service a producer is willing to supply a teach price. Price is what the producer receives for selling one unit of a good or service (Greenlaw, Steven.A., David Shapiro 2018).

The most important factors, beside the price, that affect supply are:

- Factor prices, i.e. wages, prices of machines and compensation to owners and lenders. In other words, changes in the cost of production.

- Laws and regulations that apply to the production.

International Journal of Engineering Science Technologies 
Valuation of European Put Option by Using the Quadrature Method Under the Variance Gamma Process

- Prices of other goods the firm produces or could potentially produce. Perhaps the producer is producing blue and green pens (Ahlersten n.d.).

Factors determine the supply of a particular good to a market within a given time period. As an example, suppose that you have a factory in Chennai that produces foot-ball. What factors determine how many footballs you produce and supply to the market in a span of, say, a year?

- The market price of a football itself (assuming that all footballs are exactly of the same size and quality). All else the same, if the market price of foot-ball increases, you would tend to supply more.

- Another factor is the cost of raw materials, labour and so on that go into the production of footballs. If the leather and other synthetic material with which a football is made become more expensive, it is a less profitable business and you would produce less.

- Technology also matters. If you find a more efficient way of combining labour, machines and raw materials in producing football, you would produce more. Still another factor is the price of substitute goods in production. Suppose your factory makes volleyballs as well, and to our pleasant surprise, India wins a silver medal in women's volley ball (Das 2007)

\section{Determinants of Supply:}

- Prices of related products

Goods can be substitutes or complements in production. Goods are substitutes in production if they are produced as alternatives to each other. Example: rice and vegetables (as farmer can produce one or the other on the same piece of land). Goods are complements in production if they are produced together; the production of one good implies the production of the other.

- Prices of inputs

An increase in the production cost will results in a reduction in the supply of the product. Payments for factor inputs represent a significant part of production cost.

- Technology Overtime

knowledge and production technologies change and it will affect the supply of the product. A technological change that decreases cost will increase profits earnedat any given price.

- Expectations

If producers expect prices to rise in the future, now they might begin to expand their productive capacity and thus increase their present output levels.

- Number of Producers

Obviously, the number of sellers in the market will have some effect on the total market supply (Shabeer, Sri K.P., Chacko Jose, K.Rajan 2011).

\subsection{LABOR}

Labor is the amount of physical, mental, and social effort used to produce goods and services in an economy. It supplies the expertise, manpower, and service needed to turn raw materials into finished products and services (Amadeo n.d.).

Labor is measured by the labor force or labor pool (Bureau of Labor Statistics n.d.).

Labor is also categorized by the nature of the relationship with the employer (Department of Labor n.d.)

Most workers are wage employees. This means they are supervised by a boss. They also receive a set weekly or bi-weekly wage as well as benefits (Bureau of Labor Statistics n.d.).

Labor welfare work may be divided into three categories as follows:

- Stature Welfare

It includes all those labour welfare activities which are undertaken by the employers because of legal requirements like certain types of safety measures as provided.

- Voluntary Welfare

It covers all those welfare activities which are undertaken by the employers at their own like facilities provided for housing, medical, education, transport, recreation, etc.

- $\quad$ Mutual Welfare

International Journal of Engineering Science Technologies 
It embraces all those activities which are undertaken by the workers themselves through the platform of their trade unions (Sharma 2016).

\subsection{CORONA VIRUS DISEASE 2019 (COVID-19)}

Covid-19 is a respiratory illness that can spread from person to person. The virus that causes Covid-19 is a novel coronavirus that was first identified during an investigation into an outbreak in Wuhan, China. It is currently spreading from person to person in parts of the world, including Indonesia. On March 11, 2020, the World Health Organization (WHO) has declared the 2019-2020 coronavirus outbreak a global pandemic.

Coronaviruses are a family of viruses that can cause illnesses such as the common cold, severe acute respiratory syndrome (SARS) and Middle East respiratory syndrome (MERS). In 2019, a new coronavirus was identified as the cause of a disease outbreak that originated in China. The virus is now known as the severe acute respiratory syndrome coronavirus 2 (SARS-CoV-2). The disease it causes is called coronavirus disease 2019 (Covid-19). In March 2020, the World Health Organization (WHO) declared the Covid-19 outbreak a pandemic (https://www.mayoclinic.org/diseases-conditions/coronavirus/symptoms-causes/syc-20479963 n.d.).

A corona virus is a virus that is found in animals and, rarely, can be transmitted from animals to humans and then spread person to person. In addition to Covid-19, other human coronaviruses have included The MERS virus, or Middle East respiratory syndrome. The SARS virus, or severe acute respiratory syndrome, which first occurred in the Guangdong province in southern China (https://familydoctor.org/condition/coronavirus/ n.d.).

Corona viruses are a large family of viruses. Some cause illness in people and others cause illness in animals. Human coronaviruses are common and are typically associated with mild illnesses, similar to the common cold. Covid-19 is a new disease that has not been previously identified in humans. Rarely, animal coronaviruses can infect people, and more rarely, these can then spread from person to person through close contact. There have been 2 other specific coronaviruses that have spread from animals to humans and which have caused severe illness in humans. These are the Severe Acute Respiratory Syndrome Coronavirus (SARS CoV) and Middle East respiratory syndrome coronavirus (MERS CoV) (https://www.canada.ca/en/public-health/services/diseases/2019-novel-coronavirus infection/symptoms.html. n.d.).

As of 3 April 2020, the Government of the Republic of Indonesia has reported 1986 confirmed cases and 181 deaths related to COVID-19, while 134 patients have recovered from the disease. WHO is working with the Indonesian Government to monitor the situation and prevent further spread of disease.

\subsection{THE IMPACT DEMAND TOWARD COVID 19}

According to the Asian Development Outlook 2020, the Covid-19 pandemic that comes with falling commodity prices and financial market turmoil will have bad implications for the Indonesian economy, as well as the world's. The situation is exacerbated by the weakening economies of several trade partners of Indonesia. Meanwhile, domestic demand is expected to weaken along with negative sentiments from the business and consumer sectors. However, as the world's economy will recover next year, Indonesia's growth is expected to gain momentum, with support of investment reform policies that he government recently issued (https://en.tempo.co/read/1327451/covid-19-adb-projects-indonesia-economic-growth-at-2-5, 3 April 2020 n.d.). This condition is exacerbated by several countries that apply lockdown policies that affect the import of raw materials and capital goods. Eventually production falls, scarce goods and prices rise. The increase in the price of goods accompanied by declining income is a fatal condition of people's purchasing power (https://www.tagar.id/covid19-dan-solusi-atasi-dampak-krisis-ekonomi n.d.).

According to the 2020 Asian Development Outlook (ADO), the COVID-19 pandemic along with falling commodity prices and financial market turmoil, will have bad implications for the world economy and Indonesia this year, especially with the deteriorating economy of a number of Indonesia's major trading partners. Domestic demand is expected to weaken in line with declining business and consumer sentiment (https://economy.okezone.com/read/2020/04/05/20/2194365/prediksi-adb-soal-ekonomi-indonesia-ditengah-dampak-covid-19 n.d.). Based on the description above, the hypothesis is formulated as follows:

H1: There is influence of demandon Covid 19 
Valuation of European Put Option by Using the Quadrature Method Under the Variance Gamma Process

\subsection{THE IMPACT SUPPLY TOWARD COVID 19}

Now this supply factor becomes a crucial factor. Production stopped because employees did not work due to the threat of corona. Imagine that monetary is too loose, there is a lot of money in circulation but there are no goods because production has stopped, what happens is hyperinflation, the beneficiaries are hoarders (https://finance.detik.com/berita-ekonomi-bisnis/d-4961412/assessing the government's way to face corona strike n.d.).

On the other hand, at the supply level, international scale manufacturers will be forced to rethink where to buy raw materials and produce their goods. Something that will accelerate social shifts and changes, after the US-China trade war, after the discovery of weaknesses, from the cause of relying on just one source, as the basis for product components (https://nusantaranews.co/post -covid new world order 19th/ n.d.).

Fornano \& Wolf researchers (Corona and Macroeconomic Policy, 2020), stated that " the corona virus outbreak will cause a negative supply shock to the world economy, by forcing factories to shut down and disrupting global supply chains ".The Institute for Development of Economics and Finance (INDEF) then abstracts the results of Fornano \& Wolf's research in a simpler language that the COVID-19 pandemic is predicted to cause supply-demandside shocks which include a decrease in the production of goods - a decrease in income - a wave of layoffs - decrease in purchasing power - decrease in demand for goods .Based on the description above, the hypothesis is formulated as follows :

H2: There is influence of supply on Covid 19

\subsection{THE IMPACT LABOR TOWARD COVID 19}

Indonesia has a complex system of district and provincial level minimum wages that are annually revised. As the regulatory environment for minimum wage setting in Indonesia is decentralized, discrepancies have emerged between regions. For example, in 2016 Gunung Kidul district in Yogyakarta had the lowest minimum wage (Rp.1,235,700) in Indonesia and DKI Jakarta had the highest minimum wage (Rp.3.1 million) in Indonesia -2.5 times higher even though the provinces are on the same island. An advantage of these large differentials is that it provides space for wage policy to complement the industrial and economic policies of local economies. In addition to district and provincial level minimum wages, sector level minimum wages exist in many areas throughout Indonesia. The system for sector minimum wages has largely developed through a bottom up process, where workers in various industries have organized and bargained for wages higher than the district or province minimum wage over time (Allen 2016).

The covid-19 pandemic, which is spreading like wildfire in Indonesia, has taken not just lives but also the earnings of millions of workers, one month after the government announced indonesia's first two confirmed cases of the virus. The Covid-19 outbreak has devastated workers' hours and earnings. Businesses have shut down factories and furloughed or laid off their employees as a result of low demand and the call for social distancing (https://www.thejakartapost.com/news/ akses April.9. 2020 n.d.).

The impact of the Covid-19 epidemic is not just a disease that affects health, but also an economic impact. In this case, as more and more workers are infected the more costs for care and production costs are covered (https://www.tagar.id/covid19-dan-solusi-atasi-dampak-krisis-ekonomi n.d.).

The production side must be safeguarded, so that not all workers will be laid off later when the goods needed by the community are not available, it is also dangerous. Imagine if in these conditions the need for staples is not available? For this reason, the production process of factories must be maintained. The government can help the safety of working workers, equipped with adequate Personal Protective Equipment (PPE).So those who need PPE are not only medical personnel, but those who continue to work to maintain a production economy are also being considered, even with lower standards as needed (https://finance.detik.com/berita-ekonomi-bisnis/d4961412/assessing the government's way to face corona strike n.d.). Based on the description above, the hypothesis is formulated as follows:

H3: There is influence of labor on Covid 19 
Covid 19: The Impact of Demand, Supply, and Labor

\section{METHODS}

\subsection{VARIABLE MEASUREMENT}

Measurement is the determination of numbers or other symbols for the characteristics of objects according to a set of predefined rules. Scale is a tool or mechanism by which individuals are distinguished as a way to differ individuals from other individuals toward research variable. Measurement of all variables in this research is using Likert Summated Ratings (LSR)method. Likert scale is used to measure attitudes, opinions, and perceptions of a person or group of people about social phenomena (Sugiyono 2017). The details of the scale are as follows:

Scale 1 = Strongly disagree

Scale 2 = Disagree

Scale 3 = Neutral

Scale $4=$ Agree

Scale 5 = Strongly agree

\subsection{DATA ANALYSIS METHOD}

In the first stage, the questionnaire must be tested by the validity and reliability tests. The validity indicates whether the instrument as measured something correctly. The reliability indicates the stability and consistency of whether the instrument measures the concept and helps determine the accuracy or goodness of a measurement. Data analysis method used in this research is multiple regression method. Multiple regression is analytical tool used to test the causality relationship of one dependent variable and several indepent variables. The steps taken in multiple regression analysis are descriptive statistic, classical assumption test, simultaneous hypothesis testing, coefficient of determination and partial hypothesis testing (Chandrarin 2017).

\subsubsection{VALIDITY TEST}

Validity test is used to measure the validity of a questionnaire. A questionnaire is valid if the question on the questionnaire is able to explain something that will be measured on that questionnaire (Ghozali 2016). This test is done by comparing the value of rcount with rtable for degree of freedom (df) $=n-2$, in this case $n$ is the number of samples. The criteria as follows:

1) rcount $>$ rtable, it means that the question in the questionnaire is valid.

2) rcount $<$ rtable, it means that the question in the questionnaire is not valid.

\subsubsection{RELIABILITY TEST}

Reliability test is a tool to measure a questionnaire that is an indicator of a variable or construct. A questionnaire is reliable if one's answers to questions or statements are consistent or stable over time. Reliability testing is done by calculating the amount of Cronbach Alpha Coeficcient for each questionnaire instrument to be tested. According to (Widiyanto 2010), a variable is reliable if

1) Cronbach Alpha Coeficcient> rtable, it means that the question in the questionnaire is valid.

2) Cronbach Alpha Coeficcient $<$ rtable, it means that the question in the questionnaire is not valid.

\subsection{CLASSICAL ASSUMPTION TEST}

Classical assumption test is conducted to examine the validity of regression model applied in fulfilling requirements. There are four steps in conducting classical assumption test: normality test; multicollinearity test; autocorrelation test; and heteroscedasticity test. In this research, the data used is cross section data. Cross sectional data is a type of data that taken at one shoot time within the appropriate constraints of a particular measurement attribute. Cross sectional data is determined based on variations of data taken at a given time. Autocorrelation is not used in data section (Chandrarin 2017). Therefore, in this research just do normality test, multicollinearity test, and heteroscedasticity test. 


\subsubsection{NORMALITY TEST}

(Ghozali 2016) stated that normality test is to examine whether the residuals of regression have been distributed normally. If the residuals are not normally distributed, the statistical test will be invalid for small sample. There are two methods in respect of examining the data is normally distributed, which are graphical analysis and statistics analysis.

\subsubsection{MULTICOLLINEARITY TEST}

According to (Ghozali 2016), stated that multicollinearity test is to test whether in the regression model have correlation among independent variables. An appropriate regression model should not have correlation among its independent variables. If independent variables are correlated, these variables are not orthogonal. The orthogonal variable is the independent variable that the correlation value among the independent variables equals zero.

\subsubsection{HETEROSCEDASTICITY TEST}

According to (Ghozali 2016), heteroscedasticity test has purpose to determine the heterogenous variance among residuals within the regression model from one to another residual observation. If the variance is similar, the homoscedasticity exists. Appropriate regression model should have its residuals to be homogenous.

\subsubsection{MULTIPLE LINEAR REGRESSION}

This research used multiple linear regression model because it involves two independent variables and one dependent variable. The regression model in this research is as follows:

$\mathrm{Y}=\alpha+\beta \_1 \mathrm{X} 1+\beta \_2 \mathrm{X} 2+\beta \_3 \mathrm{X} 3+\mathrm{e}$

Where:

$\mathrm{Y}=$ Covid 19

$\alpha=$ Constanta

$\beta 1,2=$ Coefficient regression
$\mathrm{X} 1,2,3$ =Demand, Supply, Labor

e $\quad=$ Standard Error

\subsubsection{PARTIAL HYPOTHESIS TESTING (T-TEST)}

T-test shows to what extent an independent variable has ability to individually explain the dependent variable (Chandrarin 2017), Hypothesis is accepted or rejected through t test with the following criteria:

1) When significance level $\leq 0.05$ or tcount $>$ ttable, it means independent variable individually affects dependent variable.

2) When significance level $\geq 0.05$ or tcount $<$ ttable, it means independent variable does not individually affect dependent variable.

\subsubsection{SIMULTANEOUS HYPOTHESIS TESTING (F-TEST)}

F-test shows whether independent variables simultaneously affect the dependent variable within the regression model (Ghozali 2016). The requirements of $F$ test are:

1) If level of significance $f<0.05$ or fcount $>$ ftable, independent variables simultaneously have a significant impact to dependent variables.

2) If level of significance $f>0.05$ or ftable $<$ fcount, independent variables donot simultaneously have a significant impact to dependent variables. 


\subsubsection{COEFFICIENT OF DETERMINATION (R2)}

Coefficient of determination test is an indicator shows the proportion of independent tvariables' variation which can explain variation of the dependent variable. Low value of R2 indicates that the independent variables has low ability to explain the dependent variable.

The value which is nearly one means that the independent variables has high ability to describe all information required in predicting the dependent variable. In general, research that use cross-sectional data can relatively has low coefficient of determination, because of the large variations of each observation. (Chandrarin 2017).

\section{RESULT}

\subsection{VALIDITY TEST}

Validity test is done by comparing the value of rcount with rtable for degree of freedom (df) $=\mathrm{n}-2$, in this case is the number of samples. If rcount> rtable, it means that the question in the questionnaire is valid. Using the SPSS 24 , all questions of each variable have rcount greater than rtable (0.1966). It means that all statements are capable of measuring the object of research with valid and consistent. The value of $r$ value can bee seen on table 1.

Table 1: Validity Test

\begin{tabular}{|c|c|c|c|}
\hline Variable & Question & $\begin{array}{c}\text { Pearson } \\
\text { Correlation }\end{array}$ & Notes \\
\hline \multirow{10}{*}{$\begin{array}{l}\text { Demand } \\
\left(\mathrm{X}_{1}\right)\end{array}$} & Question 1 & 0.777 & Valid \\
\hline & Question 2 & 0.735 & Valid \\
\hline & Question 3 & 0.724 & Valid \\
\hline & Question 4 & 0.744 & Valid \\
\hline & Question 5 & 0.741 & Valid \\
\hline & Question 6 & 0.728 & Valid \\
\hline & Question 7 & 0.738 & Valid \\
\hline & Question 8 & 0.748 & Valid \\
\hline & Question 9 & 0.717 & Valid \\
\hline & Question 10 & 0.751 & Valid \\
\hline \multirow{10}{*}{$\begin{array}{l}\text { Supply } \\
\left(\mathrm{X}_{2}\right)\end{array}$} & Question 1 & 0.651 & Valid \\
\hline & Question 2 & 0.671 & Valid \\
\hline & Question 3 & 0.676 & Valid \\
\hline & Question 4 & 0.667 & Valid \\
\hline & Question 5 & 0.639 & Valid \\
\hline & Question 6 & 0.673 & Valid \\
\hline & Question 7 & 0.632 & Valid \\
\hline & Question 8 & 0.662 & Valid \\
\hline & Question 9 & 0.628 & Valid \\
\hline & Question 10 & 0.656 & Valid \\
\hline \multirow{10}{*}{$\begin{array}{l}\text { Labor } \\
\left(X_{3}\right)\end{array}$} & Question 1 & 0.300 & Valid \\
\hline & Question 2 & 0.264 & Valid \\
\hline & Question 3 & 0.312 & Valid \\
\hline & Question 4 & 0.287 & Valid \\
\hline & Question 5 & 0.330 & Valid \\
\hline & Question 6 & 0.397 & Valid \\
\hline & Question 7 & 0.408 & Valid \\
\hline & Question 8 & 0.403 & Valid \\
\hline & Question 9 & 0312 & Valid \\
\hline & Question 10 & 0.372 & Valid \\
\hline
\end{tabular}


Valuation of European Put Option by Using the Quadrature Method Under the Variance Gamma Process

\begin{tabular}{|l|l|l|l|}
\hline \multirow{3}{*}{$\begin{array}{l}\text { Covid 19 } \\
\text { Y) }\end{array}$} & Question 1 & 0.723 & Valid \\
\cline { 2 - 3 } & Question 2 & 0.717 & Valid \\
\cline { 2 - 3 } & Question 3 & 0.713 & Valid \\
\cline { 2 - 3 } & Question 4 & 0.715 & Valid \\
\cline { 2 - 3 } & Question 5 & 0.714 & Valid \\
\cline { 2 - 3 } & Question 6 & 0.697 & Valid \\
\cline { 2 - 3 } & Question 7 & 0.691 & Valid \\
\cline { 2 - 3 } & Question 8 & 0.730 & Valid \\
\cline { 2 - 3 } & Question 9 & 0.700 & Valid \\
\cline { 2 - 3 } & Question 10 & 0.738 & \\
\hline
\end{tabular}

\subsection{RELIABILITY TEST}

Table 2: Realibility Test

\begin{tabular}{|c|c|}
\hline \multicolumn{2}{|c|}{ Reliability Statistics } \\
\hline Cronbach's Alpha & N of Items \\
\hline .421 & 4 \\
\hline
\end{tabular}

Source: Prepared by the writer (2020)

Table 2 shows that cronbach's alpha is 0421. According to Nunally as cited in (Widiyanto 2010), variable is reliable if value of cronbach's alpha (0.421) is greater than $r$ table (0.1946). It means that the the questionnaire in this research is reliable and can be used.

\subsection{NORMALITY TEST}

Normality test is used to examine whether the residuals within regression model have normal distribution. Should be known that t-test and f-test assume residuals in normal distribution. Normality test can be conducted through histogram analysis such as the following charts.

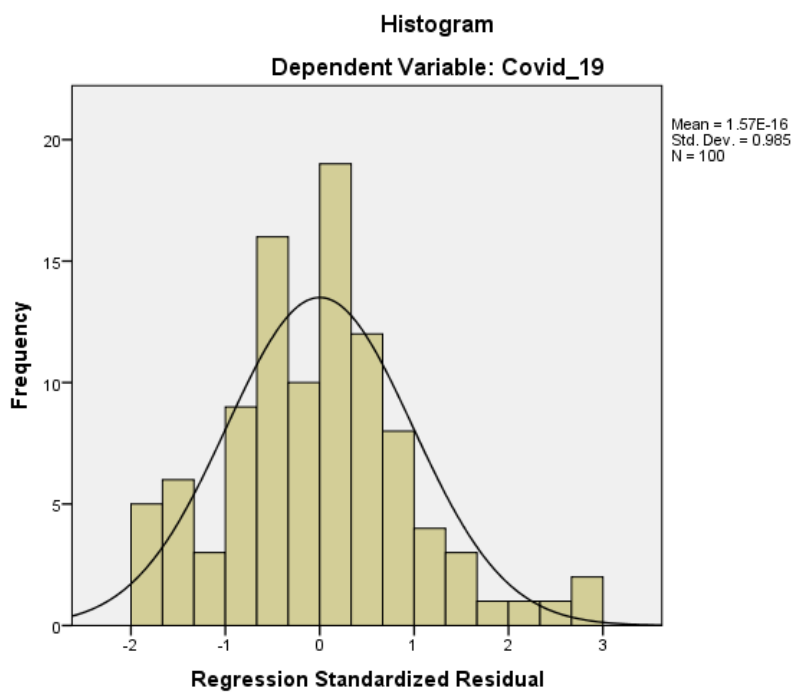

Source: Prepared by the writer (2020)

Figure 1: Histogram Analysis

Based on figure 1, histogram shows the normal distribution among the variables and does not represent positive or negative skewness. This indicates the data are normally distributed.

Examining normality of residuals by using graphical analysis may be bias visually. Therefore, it is important for the writer to conduct statistical analysis by implementing Kolmogorov-Smirnov (K-S) test on the residuals. 
Table 3: One Sample Kolmogorov - Smirnov Normality Test

\begin{tabular}{|l|c|c|}
\hline \multicolumn{3}{|c|}{ One-Sample Kolmogorov-Smirnov Test } \\
\hline \multicolumn{2}{|c|}{$\mathrm{N}$} & Unstandardized Residual \\
\hline Normal Parameters $\mathrm{a}, \mathrm{b}$ & Mean & 100 \\
\cline { 2 - 3 } & Std. Deviation &, 0000000 \\
\hline \multirow{2}{*}{ Most Extreme Differences } & Absolute & .82694872 \\
\cline { 2 - 3 } & Positive & .067 \\
\cline { 2 - 3 } & Negative & -.049 \\
\hline \multicolumn{2}{|c|}{ Test Statistic } & .067 \\
\hline \multicolumn{2}{|c|}{ Asymp. Sig. (2-tailed) } & .200 c,d \\
\hline a. Test distribution is Normal. \\
\hline b. Calculated from data. \\
\hline c. Lilliefors Significance Correction. \\
\hline d. This is a lower bound of the true significance. \\
\hline
\end{tabular}

Source: Prepared by the writer (2020)

Based on the table 3, it can be concluded that the value of Kolmogorov-Smirnov test statistic is 0.067 and asymptotic significant (2-tailed) at 0.200 which is bigger than 0.05 . It means that the residuals are normally distributed.

\subsection{MULTICOLLINEARITY TEST}

Multicollinearity test is purposely implemented to examine the correlation among tested independent variables. A proper regression model should not possess correlation among its independent variables. These are the following results of correlation matrix and tolerance value as well as its variance inflation factor (VIF).

Table 4: Tolerance Value and Variance Inflation Factor

Source: Prepared by the writer (2020)

\begin{tabular}{|c|c|c|c|}
\hline \multicolumn{2}{|c|}{ Model } & \multicolumn{2}{c|}{ Collinearity Statistics } \\
\cline { 2 - 4 } & Tolerance & VIF \\
\hline \multirow{2}{*}{1} & (Constant) & & \\
\cline { 2 - 4 } & Demand & .886 & 1.155 \\
\cline { 2 - 4 } & Tax Avoidance & .882 & 1.134 \\
\cline { 2 - 4 } & Service Quality & .996 & 1.035 \\
\hline
\end{tabular}

Based on table 4.all of the independent variables have tolerance value $\geq 0.10$ and VIF $\leq 10$. It proves that tolerance value and variance inflation factor (VIF) of the independent variables have no correlation one to another.

\subsection{HETEROSCEDASTICITY TEST}

Heteroscedasticity test is purposely examined to determine the variance inequality of residuals from one observation to another. If the variance is equal from one to another observation, it called as homocedasticity. Proper regression model occurred when it has homocedasticity variance, not heteroscedasticity. It is conducted by Scatterplot analysis with the following results. 


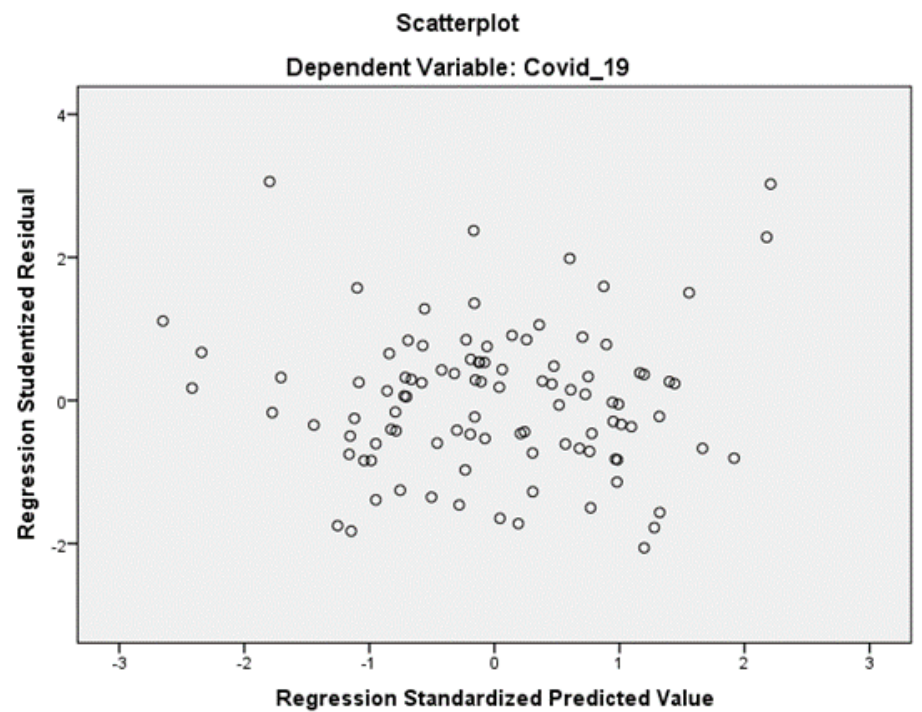

Source: Prepared by the writer (2020)

Figure 2: Scatterplot Analysis

Based on figure 2, the dots are widely distributed which do not create a specified pattern of distribution. It shows the residuals have high possibility of being homecedastic. However, the scatterplot analysis can be subjective due to visual decision making.

\subsection{REGRESSION MODEL}

Table 5: Regression Model

\begin{tabular}{|c|c|c|c|c|c|}
\hline \multicolumn{5}{|c|}{ Coefficients $^{\mathrm{a}}$} \\
\hline \multirow{2}{*}{ Model } & Unstandardized Coefficients & Standardized Coefficients & $\mathrm{t}$ & Sig. \\
\cline { 2 - 6 } & $\mathrm{B}$ & Std. Error & Beta & & \\
\hline 1 (Constant) & 29.314 & 5.180 & & 5.659 & .000 \\
\hline Demand & .341 & .086 & .387 & 3.982 & .000 \\
\hline Supply & .071 & .087 & .079 & .820 & .414 \\
\hline Labor & -.294 & .105 & -.258 & -2.806 .006 \\
\hline
\end{tabular}

a. Dependent Variable: Covid 19

Source: Prepared by the writer (2020)

Based on table 5, multiple linear regression equations can be arranged as follows.

Covid $19=29.314+0.341$ Demand + 0.071 Supply- 0.294 Labor

\subsection{PARTIAL HYPOTHESIS TESTING (T-TEST)}

Table 6: Partial Hypothesis Testing (T-Test)

\begin{tabular}{|c|c|c|c|c|c|}
\hline \multicolumn{6}{|c|}{ Coefficientsa } \\
\hline \multirow{2}{*}{ Model } & Unstandardized Coefficients & Standardized Coefficients & $\mathrm{t}$ & Sig. \\
\cline { 2 - 5 } & $\mathrm{B}$ & Std. Error & Beta & & \\
\hline 1 (Constant) & 29.314 & 5.180 & & 5.659 & .000 \\
\hline Demand & .341 & .086 & .387 & 3.982 & .000 \\
\hline Supply & .071 & .087 & .079 & .820 & .414 \\
\hline Labor & -.294 & .105 & -.258 & -2.806 .006 \\
\hline
\end{tabular}

a. Dependent Variable: Covid 19

Source: Prepared by the writer (2020) 
The value of ttable with two tailed significance level of 0.05 at a degree of freedom of $96(100-3-1)$ is 1.984 . Therefore, the outcomes of partial hypothesis testing in accordance with table 6 are as follows.

- Demand variable has tcount of 3.982 with level of significance of 0.00 . It can be concluded that tcount(3.982) $>$ ttable (1.984) and $0.00<0.05$ which indicates that demand variable partially is influences the covid 19.

- Supply variable has tcount of .820 with level of significance of 0.414 . It can be concluded that tcount $(0.820)<$ t table $(1.984)$ and $0.414>0.05$ which indicates that supply variable partially is not influences the covid 19.

- Service Quality variable has tcount of -2.806 with level of significance of 0.006 . It can be concluded that tcount(2.806) $>$ ttable(1.984) and $0.006<0.05$ which indicates that labor variable partially is influences the covid 19.

\subsection{SIMULTANEOUS HYPOTHESIS TESTING (F-TEST)}

Table 7: Simultaneous Hypothesis Testing (F-Test)

\begin{tabular}{|c|c|c|c|c|c|c|}
\hline \multicolumn{7}{|c|}{ ANOVA $^{a}$} \\
\hline & Model & Sum of Square & & Mean Square & $\mathrm{F}$ & Sig. \\
\hline \multirow[t]{3}{*}{1} & Regression & 398.682 & 3 & 132.894 & 8.799 & $.000^{\mathrm{b}}$ \\
\hline & Residual & 1449.908 & 96 & 15.103 & & \\
\hline & Total & 1848.590 & 99 & & & \\
\hline \multicolumn{7}{|c|}{ a. Dependent Variable: Covid_19 } \\
\hline \multicolumn{7}{|c|}{ b. Predictors: (Constant), Labor,Supply, Demand } \\
\hline
\end{tabular}

Source: Prepared by the writer (2020)

Based on table 7, the fcount of regression model is 8.799. The first degree of freedom (df1) $=\mathrm{k}-1=4-1=3$, while the second degree of freedom (df2) $=\mathrm{n}-\mathrm{k}=100-4=96$ in which $\mathrm{n}$ represents the amount of samples and $\mathrm{k}$ represents the amount of variables. With the df1 of 3 and df2 of 96, the Ftable with confidence level of 0.05 is 2.70 . Therefore, the $\mathrm{f}$ count (8.799) $>\mathrm{f}$ table (2.70) as well as significance value of $0.00<0.05$ which indicates that both of the independent variables are simultaneously affecting the covid 19.

\subsection{COEFFICIENT OF DETERMINATION (R2)}

The coefficient of determination is essentially used to measure the ability of the model in explaining the variation of the dependent variable. The result of determination test can be seen as follows

Table 8: Coefficient of Determination

\begin{tabular}{|c|c|c|c|c|}
\hline \multicolumn{4}{|c|}{ Model Summaryb } \\
\hline Model & R & R Square & Adjusted R Square Std. Error of the Estimate \\
\hline 1 & .464 a & .216 & .191 & 3.886 \\
\hline \multicolumn{4}{|c|}{ a. Predictors: (Constant), Labor, Supply, Demand } \\
\hline \multicolumn{4}{|c|}{ b. Dependent Variable: Covid_19 } \\
\hline
\end{tabular}

Source: Prepared by the writer (2020)

Based on table 8 , R Square of the regression model is 0.216 which shows that $21.6 \%$ of mitigation of covid 19 can be explained by demand, supply, labor. Whereas, the $78.4 \%$ of covid 19 variable can be explained by other factors or variables which are not examined in this research.

\section{The Impact Demand of Covid 19}

The result of ttest on demand variable has tcount(3.982) > ttable(1.984) with level of significance of 0.00. It means $\mathrm{H} 1$ which hypothesizes affect demand is approved. The t test indicates taxation system has great impact on affecting the covid 19 . This is in line with research conducted by 


\section{The Impact Supply of Covid 19}

The result of $t$ test on supply variable has tcount $(0.820)<\operatorname{ttable(1.984)~with~level~of~significance~of~} 0.414$. It means $\mathrm{H} 2$ which hypothesizes affect supply is not approved. The t test indicates supply has less impact on affecting the covid 19. This is in line with research conducted by

\section{The Impact Labor of Covid 19}

The result of ttest on labor variable has tcount (2.806)> ttable(1.984) with level of significance of 0.006. It means H3 which hypothesizes affect labor is approved. The t test indicates labor has great impact on affecting the covid 19. This is in line with research conducted by

\section{SOURCES OF FUNDING}

This research received no specific grant from any funding agency in the public, commercial, or not-for-profit sectors.

\section{CONFLICT OF INTEREST}

The author have declared that no competing interests exist.

\section{ACKNOWLEDGMENT}

None.

\section{REFERENCES}

[1] Ahlersten, Krister. Microeconomics. Bookboon.com.

[2] Allen, Emma R. 2016. "Analysis of Trends and Challenges In The Indonesian Labor Market. ADB Papers on Indonesia.” Asian Development Bank.

[3] Amadeo, Kimberly. "Demand, Its Explanation, and Its Impact." https://www.thebalance.com/ .

[4] Bureau of Labor Statistics. "How the Government Measures Unemployment."

[5] Chandrarin, G. 2017. Metode Riset Akuntasi Pendekatan Kuantitatif. Jakarta: Salemba Empat.

[6] Das, Satya P. 2007. "Microeconomics for Business. Sage Publications India Pvt Ltd."

[7] Debertin, David L. 2012. “Applied Microeconomics.” In University of Kentucky.Lexington, KY.

[8] Deepashree. 2018. "Saraswati Introductory Microeconomics.” In New Saraswati House (India) Pvt.

[9] Departement of Labor. "Employment Relationship Under the Fair Labor Standards Act (FLSA)."

[10] Ghozali, Imam. 2016. Aplikasi Analisis Multivariete Dengan Program IBM SPSS 23. 8 ed. Semarang: Badan Penerbit Universitas Diponegoro.

[11] Greenlaw, Steven.A., David Shapiro, Timothy Taylor. 2018. “Principles of Microeconomics 2e.” In Openstax.

[12] Hofstrand, Don. 2019. "Demand." In Iowa State University, Extention and Outreach.

[13] "https://economy.okezone.com/read/2020/04/05/20/2194365/prediksi-adb-soal-ekonomi-indonesiadi-tengah-dampak-covid-19."

[14] "https://en.tempo.co/read/1327451/covid-19-adb-projects-indonesia-economic-growth-at-2-5, 3 April 2020." https://en.tempo.co/read/1327451/covid-19-adb-projects-indonesia-economic-growth-at-2-5, 3 April 2020.

[15] "https://familydoctor.org/condition/coronavirus/."

[16] "https://finance.detik.com/berita-ekonomi-bisnis/d-4961412/assessing the government's way to face corona strike."

[17] "https://idcloudhost.com/Explore how the impact of Corona Virus (Covid-19) on the Indonesian economy."

[18] "https://nusantaranews.co/post -covid new world order 19th/."

[19] "https://www.canada.ca/en/public-health/services/diseases/2019-novel-coronavirus infection/symptoms.html."

[20] "https://www.mayoclinic.org/diseases-conditions/coronavirus/symptoms-causes/syc-20479963." 
[21] "https://www.tagar.id/covid19-dan-solusi-atasi-dampak-krisis-ekonomi."

[22] "https://www.thejakartapost.com/news/ akses April.9. 2020."

[23] L.N., Safiullin, OduntsovaJ.L., Safiullin N.Z. 2015. "The theory of demand in the conditions of heterogeneity of goods and consumers. International Conference on Applied Economics (ICOAE)." Procedia Economics and Finance 24: $288-295$.

[24] Moffatt, Mike. “Definiton of Demand." https://www.thoughtco.com/.

[25] Reynolds. 2011. "Basic Microeconomics." In Boise State University,College Textbook.

[26] Shabeer, Sri K.P., Chacko Jose, K.Rajan, M.P.Abdulla. 2011. "Micro Economics I.” In University of Calicut.

[27] Sharma, R.C. 2016. "Industrial Relations and Labour Legislation. PHI Learning Private Limited." In New Delhi.

[28] Sugiyono. 2017. Metode Penelitian Kuantitatif, Kualitatif, dan R\&D. Bandung: CV Alfabeta.

[29] Widiyanto, Joko. 2010. SPSS for Windows Untuk Analisis Data Statistik dan Penelitian. Surakarta: BP-FKIP UMS. 